\title{
Evidence on a New Stock Trading Rule that Produces Higher Returns with Lower Risk
}

\author{
Eric L. Prentis \\ Prentis-Business \\ Houston, TX 77024, USA \\ Tel: 281-851-5555Ｅ-mail: eric.prentis@gmail.com
}

\begin{abstract}
This new stock market trading rule uses three steps to remove random unsystemic risk from stock price data to smooth volatility. Proving empirically that a technical analysis relative maxima and minima trading rule for an S\&P 500 Index portfolio substantially beats a naïve buy-and-hold policy, at significantly lower risk. Calling key theories in economics and finance into question. The new trading rule succeeds because of market participants' emotions. Investor fear and panic selling plunges stock prices downward below equity intrinsic values at market bottoms. Investor greed brings prices above equity intrinsic values at market tops.
\end{abstract}

Keywords: Stock market, Rational expectations theory, Efficient market theory, Technical analysis

\section{Introduction}

This research empirically tests the Rational Expectations Theory (RET) and the Efficient Market Theory (EMT), key theories in economics and finance. The important question is, are markets efficient? If markets are inefficient, a key premise becomes questionable.

Existing research on the efficiency of the United States (US) stock market-using either statistical inference or trading rules - is inconclusive. This empirical research on a new technical analysis relative maxima and minima trading rule tests the RET and EMT - and is the first to report in the literature, clear evidence of substantially beating the US stock market at significantly lower risk-over 81 years of data. Calling the RET and EMT into question.

The rest of the paper's organization is as follows: Section 2 discusses the relevant literature. Section 3 explains the new stock trading rule. Section 4 presents the data selection and research method. Section 5 analyses the empirical results while Section 6 offers final remarks.

\section{Literature Review}

Is the US stock market efficient? The Rational Expectations Theory (RET) (Muth, 1961), and (Lucas, 1972) and the Efficient Market Theory (EMT) (Samuelson, 1965) and (Fama, 1965, 1970) define efficient markets and are the dominant theories in economics and finance (Fama, 1991, 1998), (Malkiel, 2005), and (Peress, 2010).

A major RET tenet - supporting the EMT - assumes organizations and individuals who engage in an institutional marketplace, even when their decisions and actions are irrational, produces systemically correct markets. The marketplace produces rational results through the regulating influence of other rational participants. A critique of this RET assumption points out that it does not maximize utility for rational investors who understand irrational market forces and decide the current price trend advance does not match market fundamentals. And - based on correct timing — want to make more money during the market run-up and get out of the stock market or go short —at the correct time - before the market plummets downward (Graham, Harvey, and Huang, 2009).

The EMT defines markets as: 1) being in equilibrium and if unexpected events cause disequilibrium, it is only temporary, markets are self-equilibrating; 2) asset prices "fully reflect" all available information, properly represent each asset's intrinsic value, and as a result, prices are always accurate signals for capital allocation; and 3) stock prices move randomly or are uncorrelated with, if not independent of the prior period's price change. So, beating the stock market is impossible to achieve using either technical analysis or stock charts. Therefore, says the EMT, if investors want to earn more money than the stock market, they have to take on more risk. This research empirically tests this third EMT tenet.

Grossman and Stiglitz (1980) challenge tenet number one. A stock market always in equilibrium and efficient is impossible because traders have different endowments, beliefs and preferences. Arbitrage costs throw markets out of equilibrium, making markets necessary which calls the EMT into question. The current credit crisis and the US government's use of anywhere from \$3-to-\$24 trillion taxpayer dollars and Federal debt guarantees to stabilize the financial system is a recent real-life example that markets are not self-equilibrating.

In tenet number two, of the EMT's definition of markets - that stock prices "fully reflect" all information - has long been challenged in the literature (Ball and Brown, 1968). Post-earnings-announcement drift survives robustness checks, including extensions to more recent data. Bernard and Thomas (1990) study earnings announcements and find evidence of three-day abnormal return predictability, based on one-to-four prior quarterly earnings announcements. Gift, Gift and Yang (2010) report the stock market responds only gradually to new information. 
Critiques in the literature of the EMT's tenet number two - of asset prices always being at their intrinsic values and accurate signals for correct capital allocation - stress that this EMT assumption does not account for human nature and inherent herding behavioral instincts. Where speculating occurs in response to the madness of crowd behavior rather than on market fundamentals, resulting in market bubbles (Shiller, 2000), (Blasco and Ferreruela, 2008), and (Hsieh, Yang and Yang, 2010). The Technology Bubble in 2000, the Oil Bubble in July, 2008, as well as many bubbles throughout history (i.e., John Law's Mississippi Scheme, the South Sea Bubble and Holland's Tulip Mania) and now the Real Estate Bubble. Where nationally, US home prices have on average declined about $30 \%$ since June, 2006, with a further weakening in home prices expected. Are compelling real-life examples that market bubbles do occur and that market prices cannot always be counted on for correct capital allocation.

Lo and MacKinlay (1988) challenge tenet number three - that stock prices follow a random walk. Rosenberg and Rudd (1982), Ashley (1986), and Summers (1986) test and critically question the serial independence of stock prices. The risk and return of individual company common stock prices are compared with a buy-and-hold benchmark S\&P 500 Index portfolio and presented in the literature (Basak, Jagannathan and Ma, 2009), but—on market efficiency-researchers report uncertain results.

Trading rules in the literature also examine tenet number three. Curcio, Goodhart, Guillaume and Payne (1997) test filter rules, reporting poor to average daily return results. Sullivan, Timmermann and White (1999) test 7,846 trading rules, including moving averages, support and resistance, filter rules, channel breakouts, benchmark, span-of-the-trading rules and on-balance volume averages - on Dow Jones Industrial Average data over 90 years - and report inconclusive results. Lento (2009) tests nine trading rules on data from fifteen of the largest global equity markets, reporting indefinite results. The existing research does NOT convincingly evaluate the third EMT tenet for the US stock market, until now.

Scientific testing of the third EMT tenet takes place in this research-using a new technical analysis relative maxima and minima trading rule to make buy and sell decisions, consistently applied over 81 years. This empirical research shows how to beat, by a wide margin, the US stock market (i.e., a naïve buy-and-hold policy) at significantly lower risk. Calling the RET and EMT into question.

\section{New Stock Trading Rule}

The underlying motivation for this new technical analysis trading rule comes from Edwards, Magee, and Bassetti (2001). Investors use a 200-day simple moving average (SMA) trend line to identify the long-term direction of the stock market. If up-trending, a bull market and investing in equities is the correct choice. If down-trending, a bear market and NOT investing in equities is the correct choice. This study uses monthly data, the nine-month SMA trend line is close to the 200-day duration. The 50-day SMA trend line is used for crossovers and penetrations, to decide turning points in the long-term direction of the stock market. With monthly data, the two-month SMA trend line is close to the 50-day duration.

Using calculus, the nine and two-month SMA trend lines are converted into a mathematical model. Nine and two-month SMA trend lines are NOT used with individual company common stock price data, because of individual stock's random unsystemic risk behavior. But rather, only with the steady, systemic market risk of large company, capitalization-weighted, well diversified S\&P 500 Index portfolios.

\subsection{Relative Maxima: Sell Stock}

To identify a change in the long-term uptrend in the stock market, the first derivative $\left(f^{\prime}\right)$ of the S\&P 500 Index portfolio B nine-month SMA trend line function $f\left(\mathrm{~L}_{9}\right)$ is calculated immediately after the close of trading on the last trading day of each month - at time t. The S\&P 500 Index nine-month SMA trend line function $f\left(\mathrm{~L}_{9}\right)$ is increasing and positive when its first derivative is greater than zero:

$$
f^{\prime}\left(\mathrm{L}_{9}\right)>0
$$

The transition from topping or rounding over to a long-term downtrend is identified by finding the relative maxima for the S\&P 500 Index nine-month SMA trend line function $f\left(\mathrm{~L}_{9}\right)$, where its first derivative $f^{\prime}\left(\mathrm{L}_{9}\right)>0$ changes to a negative slope:

$$
f^{\prime}\left(\mathrm{L}_{9}\right)<0
$$

Find:

$$
m_{9} \leq \tan \left(355^{\circ}\right) \text {, at time } \mathrm{t}
$$

Equation (3) is valid when the S\&P 500 Index nine-month SMA trend line function $f\left(\mathrm{~L}_{9}\right)$ slope $\left(m_{9}\right)$, at time $\mathrm{t}$, is less than or equal to the slope of a 355 degree tangent line. A transition from topping or rounding over to long-term downtrend is partially confirmed and subject to the following two conditions- both of which are needed for the "relative maxima: sell stock" decision to be declared.

Subject to,

First:

$$
m_{2} \leq \tan \left(353^{\circ}\right) \text {, at time } \mathrm{t}
$$


Equation (4) is valid when the S\&P 500 Index two-month SMA trend line function $f\left(\mathrm{~L}_{2}\right)$ slope $\left(m_{2}\right)$, at time t, is less than or equal to the slope of a 353 degree tangent line. A "relative maxima: sell stock" transition from topping or rounding over to long-term downtrend is partially confirmed, and:

Second:

$$
\mathrm{X}_{1} \text { and/or } \mathrm{X}_{2} \leq f\left(\mathrm{~L}_{9}\right) \text {, for month } \mathrm{t}
$$

$\mathrm{X}_{1}$ is the opening S\&P 500 Index price for month $t$, while $\mathrm{X}_{2}$ is the closing price for month $t$. When either the opening price for month $\mathrm{t}$ or the closing price for month $\mathrm{t}$ - or both the opening and closing prices for month $\mathrm{t}$-are less than (below) or equal to the S\&P 500 Index nine-month SMA trend line function $f\left(\mathrm{~L}_{9}\right.$ ), equation (5) is valid.

A transition from topping or rounding over to a long-term downtrend is confirmed for the S\&P 500 Index portfolio B nine and two-month SMA trend lines when equations (2), (3), (4) and (5), for month t, are all valid. A "relative maxima: sell stock" decision is declared. All portfolio B shares are redeemed from the S\&P 500 Index no-load mutual fund and invested in the risk-free 3-month Treasury bill (T-bill) interest bearing account, at the close of trading on the first trading day of the following month (i.e., $t+1$ ).

\subsection{Relative Minima: Buy Stock}

To identify a change in the long-term downtrend in the stock market, the first derivative $\left(f^{\prime}\right)$ of the S\&P 500 Index portfolio B nine-month SMA trend line function $f\left(\mathrm{~L}_{9}\right)$ is calculated immediately after the close of trading on the last trading day of each month - at time t. The S\&P 500 Index nine-month SMA trend line function $f\left(\mathrm{~L}_{9}\right)$ is decreasing and negative when its first derivative is less than zero:

$$
f^{\prime}\left(\mathrm{L}_{9}\right)<0
$$

The transition from accumulation or bottoming to a long-term uptrend is identified by finding the relative minima for the S\&P 500 Index nine-month SMA trend line function $f\left(\mathrm{~L}_{9}\right)$, where its first derivative $f^{\prime}\left(\mathrm{L}_{9}\right)<0$ changes to a positive slope:

$$
f^{\prime}\left(\mathrm{L}_{9}\right)>0
$$

Find:

$$
m_{9} \geq \tan \left(5^{\circ}\right) \text {, at time } \mathrm{t}
$$

Equation (8) is valid when the S\&P 500 Index nine-month SMA trend line function $f\left(\mathrm{~L}_{9}\right)$ slope $\left(m_{9}\right)$, at time $\mathrm{t}$, is greater than or equal to the slope of a five-degree tangent line. A transition from accumulation or bottoming to long-term uptrend is partially confirmed and subject to the following condition which is needed for the "relative minima: buy stock" decision to be declared.

Subject to,

$$
\text { If (2), (3), (4) and (5) at time t; then } f^{\prime}\left(\mathrm{L}_{9}\right)<0 \text {, for months } \mathrm{t}+1 \text { and } \mathrm{t}+2
$$

Once a transition from topping or rounding over to a long-term downtrend is confirmed as valid, for month $\mathrm{t}$, that declaration shall remain in force for the next two months (i.e., $\mathrm{t}+1$ and $\mathrm{t}+2$ ), defining a negative slope for $f^{\prime}\left(\mathrm{L}_{9}\right)$. At stock market peaks, $f^{\prime}\left(\mathrm{L}_{9}\right)$ can fluctuate: down, up, down. Therefore, a "relative minima: buy stock" decision should not be declared within two months of a "relative maxima: sell stock" declaration.

A transition from accumulation or bottoming to a long-term uptrend is confirmed for the S\&P 500 Index portfolio B nine and two-month SMA trend lines when equations (7), (8) and (9), for month $t$, are all valid. A "relative minima: buy stock" decision is declared. All portfolio B funds are taken from the risk-free 3-month T-bill interest bearing account and invested in the S\&P 500 Index no-load mutual fund, at the close of trading on the first trading day of the following month (i.e., $\mathrm{t}+1$ ).

Once the long-term stock market trend is identified — dependent on the S\&P 500 Index portfolio B "relative maxima: sell stock" or "relative minima: buy stock" trading rule declarations - there is a higher likelihood the long-term stock market trend will continue, either upward or downward.

\subsection{Flowchart: New Stock Trading Rule Method}

A flowchart of the relative maxima and minima trading rule's method is drawn in Figure 1. Portfolio B: relative maxima and minima trading rule flowchart. This diagrams how the relative maxima and minima trading rule equations decide when to move actively managed portfolio B from the S\&P 500 Index no-load mutual fund to the risk-free 3-month T-bill interest bearing account, and back.

The portfolio B switching program is run in Figure 1, between the overall starting and ending points of this empirical research, once the starting and ending investment positions for this study are established. The beginning point of this study is January 3, 1928, the stock market was then up-trending (equation (1) $f^{\prime}\left(\mathrm{L}_{9}\right)>0$ ). Therefore, both portfolios A and B begin this study originally invested in S\&P 500 Index no-load mutual funds. At this study's 
conclusion, on December 31, 2008, all portfolio A and B S\&P 500 Index no-load mutual fund shares or 3-month T-bills are redeemed for cash-for comparison purposes.

To explain relative timing labels: this month's data is at time $t$, last month's data is $t-1$ and next month's data is $t+1$. When next month's new data becomes available, that is now the data at month $t$, and this month's data becomes one-month old and labeled, t-1. A detailed description of what occurs in Figure 1 standard flowchart symbols - each month the portfolio B switching program is run-follows:

Start Program, for Month t.-Immediately after the close of trading on the last trading day of month $\mathrm{t}$ - the relative maxima and minima trading rule program is run. Go to the NEXT STEP.

Enter New Data, for Month t.-Enter, after the close of trading on the last trading day of month $t$, the new month's open, high, low and closing prices for the S\&P 500 Index. Go to the NEXT STEP.

Has the Stock Market Been Up-Trending?-If YES, the S\&P 500 Index nine-month SMA trend line function $f$ $\left(\mathrm{L}_{9}\right)$ has been increasing and positive, its first derivative has been greater than zero: (1) $f^{\prime}\left(\mathrm{L}_{9}\right)>0$, for t-1. Resulting in portfolio B being invested during the prior month in the S\&P 500 Index no-load mutual fund. When portfolio B has been invested at t-1 in the S\&P 500 Index no-load mutual fund, Go to the NEXT STEP.

Equations: Are (2), (3), (4) and (5) Valid?-If YES, a transition from topping or rounding over to a long-term downtrend is confirmed for portfolio B. Based on the nine and two-month SMA trend lines and the opening and closing prices for month t. From here, a "relative maxima: sell stock" decision is declared. Go to the NEXT STEP.

Switch Portfolio B from Investing in the S\&P 500 Index Into 3-month T-bills. -All portfolio B shares are redeemed from the S\&P 500 Index no-load mutual fund and invested in interest bearing, risk-free 3-month T-bills - at the close of trading on the first trading day of the following month (i.e., $t+1$ ). Go to End Program for Month t.

Equations: Are (2), (3), (4) and (5) Valid?-If NO, no investment change decision is made, for month t. Portfolio B remains invested in the S\&P 500 Index no-load mutual fund. Go to End Program for Month t.

Has the Stock Market Been Up-Trending?-If NO, the S\&P 500 Index nine-month SMA trend line function $f\left(\mathrm{~L}_{9}\right)$ has been decreasing and negative, its first derivative has been less than zero: $(6) f^{\prime}\left(\mathrm{L}_{9}\right)<0$, for $\mathrm{t}-1$. Resulting in portfolio $\mathrm{B}$ being invested during the prior month in interest bearing, risk-free 3-month T-bills. When portfolio B has been invested at t-1 in interest bearing, risk-free 3-month T-bills, Go to the NEXT STEP.

Down-trending Stock Market.-The stock market was down-trending at t-1. When portfolio B has been invested at t-1 in interest bearing, risk-free 3-month T-bills, Go to the NEXT STEP.

Equations: Are (7), (8) and (9) Valid?-If YES, a transition from accumulation or bottoming to a long-term uptrend is confirmed for the S\&P 500 Index portfolio B nine-month SMA trend line for month $\mathrm{t}$-and a "relative maxima: sell stock" decision has not been declared within the last two months. From here, a "relative minima: buy stock" decision is declared. Go to the NEXT STEP.

Switch Portfolio B from Investing in 3-month T-bills Into the S\&P 500 Index.-All portfolio B funds are taken from the risk-free 3-month T-bill interest bearing account and invested in the S\&P 500 Index no-load mutual fund - at the close of trading on the first trading day of the following month (i.e., $t+1$ ). Go to End Program for Month t.

Equations: Are (7), (8) and (9) Valid?-If NO, no investment change decision is made, for month t. Portfolio B remains invested in interest bearing, risk-free 3-month T-bills. Go to End Program for Month t.

End Program, for Month t.-Program stops, for month t.

\section{Data and Method}

\subsection{S\&P Index Services Data: 1928 through 2008}

S\&P Index Services supply the S\&P 500 Index open, high, low and closing price data. The price data set-as received - begins in 1928 and goes through 2008. This research uses the entire data set from S\&P Index Services. Nine and two month simple moving average (SMA) trend lines are fit to the supplied data.

Using a long-term study of 81 years assures that stock market data are collected during normal times. As well as when the stock market is either panicking, and plunging lower under duress - or booming and surging higher with confidence - because of either fear or greed controlling investors' emotions (Lo, 2002).

Two identical S\&P 500 Index mutual funds are used, both with beta values equal to one $(B=1)$. Representing only steady, systemic market risk. S\&P 500 Index portfolio A is the buy-and-hold benchmark. Actively managed S\&P 500 Index portfolio B uses only the S\&P 500 Index nine and two-month SMA trend lines and technical analysis model - consisting of the new relative maxima and minima trading rule - to decide when to be either invested in the stock market or out and invested in interest bearing, risk-free 3-month T-bills.

\subsection{Dividend and Interest Payments}

When portfolios A and B are invested in the S\&P 500 Index, they both receive identical dividend payments. For this study, no accounting for either portfolio's accrued dividends is made during these concurrent time periods in the 
stock market. When portfolio B is transferred out of the stock market into an interest bearing account, the interest earned is at the risk-free 3-month T-bill rate. Therefore, a determination of whether 3-month T-bill interest rates are either higher or lower than S\&P 500 Index dividend yield payments is needed.

Over this empirical study from January 3, 1928 to December 31, 2008 (i.e., 972-months), S\&P 500 Index dividend yields average $3.98 \%$, based on S\&P 500 Index historical annual dividend data supplied by S\&P Index Services. During the same time period, 3-month T-bill interest rates average 3.70\%, based on data from the Federal Reserve Statistical Release. Average 3-month T-bill interest rates less than S\&P 500 Index dividend yields are expected over the entire 972-month planning horizon, given the risk-free nature of T-bills. However, the timing of dividend and interest payments concern investors.

S\&P 500 Index dividend yields and 3-month T-bill interest rates fall into two distinct main phases. The first phase is from 1928 through 1959, S\&P 500 Index dividend yields average 5.28\% and 3-month T-bills average 1.02\%. Beginning in 1960, a marked shift in corporate dividend governance lowers dividend yields and at the same time events in the economy increase 3-month T-bill interest rates. During the second phase-from 1960 through December 31, 2008-S\&P 500 Index dividend yields average 3.12\% and 3-month T-bill interest rates average $5.46 \%$.

From 1928 through 1959, portfolio B is at times out of the S\&P 500 Index no-load mutual fund and invested at the risk-free 3-month T-bill interest rate. Dividends accrue to the buy-and-hold S\&P 500 Index portfolio A at the dividend yield to interest rate differential of $4.26 \%$ (i.e., $5.28 \%-1.02 \%$ ) each year or 0.00355 each month. The number of S\&P portfolio A shares increase by dividing the dividend-interest differential earned by the S\&P 500 Index share price, when the $\mathrm{S} \& \mathrm{P}$ portfolio $\mathrm{B}$ portfolio is reinvested.

Similarly-from 1960 through 2008 - when portfolio B is periodically out of the S\&P 500 Index no-load mutual fund and invested at the risk-free 3-month T-bill interest rate. Interest accrues to portfolio B at the interest rate to dividend yield differential of $2.34 \%$ (i.e., $5.46 \%-3.12 \%$ ) each year or 0.00195 each month. The number of portfolio $\mathrm{B}$ shares increase by dividing the interest-dividend differential earned, by the S\&P 500 Index share price, when portfolio B is reinvested in the S\&P 500 Index no-load mutual fund.

\subsection{Why Statistical Tests Are Not Used, and the New Trading Rule Is}

When using statistical analysis to test whether individual company common stock price data are independent, it is difficult to distinguish between a rootless series and one where the steady systemic quality is faint. Summers (1986) estimates that 5,000 years of data are needed to identify independence. Five thousand years of market data are unavailable. Thus, this study does NOT use statistical inference. Instead, this paper's empirical research method directly tests stock market price independence using technical analysis. The relative maxima and minima trading rule determines whether profits are greater than a benchmark naïve buy and hold policy which Fama $(1965,1995)$ calls, "an equally valid scientific method versus statistical inference."

The technical analysis relative maxima and minima trading rule decides when portfolio B should be either in a S\&P 500 Index no-load mutual fund, or out, and invested in interest bearing, risk-free 3-month T-bills. The new technical analysis trading rule is the primary difference between this research and the statistical inference and trading rule papers found in the referenced RET and EMT research.

\subsection{EMT Theorists' Concerns Addressed}

The anomalies and direct challenges to the EMT in the referenced literature seem convincing, but have failed to satisfy EMT theorists (Fama, 1998) and (Malkiel, 2003). Their concerns are: 1) stock selection bias; 2) not adjusting returns based on greater security risk; 3 ) not calculating economic gains once transaction costs are considered; 4) not properly accounting for bid-ask spreads and a bias in recording prices; 5) not using a naïve buy-and-hold control portfolio for comparison purposes; 6) survivorship bias; 7) not testing for consistency over a long-duration time period; and 8) data-snooping biases.

EMT theorists' concerns are specifically addressed in the design of the empirical testing method and technical analysis relative maxima and minima trading rule used in this research, as follows:

Random unsystemic risk, associated with individual company common stock prices, is removed from the research data and only steady, systemic market risk remains when comparing this empirical study's two S\&P 500 Index portfolios. Thus, active portfolio management selection bias of an individual company common stock is impossible in this research.

The S\&P 500 Index buy-and-hold portfolio is portfolio A. The technical analysis relative maxima and minima trading rule S\&P 500 Index portfolio is portfolio B. The beta value of the trading S\&P 500 Index portfolio B - providing excess returns - never exceeds the beta value for the S\&P 500 Index buy-and-hold portfolio A. Therefore, there is no need to adjust returns based on greater risk.

No-load mutual fund transaction costs are zero, for both S\&P 500 Index portfolios A and B.

The bid-ask spread and whether closing prices can be realized are NOT issues in this research. Because, no-load mutual fund companies calculate their net asset values at the trading day's close which is the trading point in this 
study. In addition, the buy or sell trading signal is given one business day before the stock mutual fund trading day in this empirical research, allowing enough time to make the trade. Thus, a bias in recording prices is impossible.

The S\&P 500 Index has long been employed as a control benchmark by researchers to evaluate specific portfolio selection methods. As an important variation in this empirical research, two S\&P 500 Index portfolios are used for comparison purposes, one for trading and the other as the naïve buy-and-hold control portfolio. Identical investment portfolios are compared, consisting of two S\&P 500 Index no-load mutual funds. Distinguished solely by a technical analysis relative maxima and minima trading rule. Thus, a naïve buy-and-hold control portfolio is used in this research.

Survivorship bias is not an issue in this study; because, the S\&P 500 Index does not go bankrupt, as with the possibility for an individual company.

A long-duration empirical study of the data from 1928 through 2008, totaling 81 years, proves that long-term trends are reliable over an extended time period, covering both good economic times and bad.

Data snooping is a "statistical testing bias" where an extensive number of hypotheses are checked by computer against a single data set. Fishing for statistically significant correlations between various combinations of variables, hoping that one will eventually become obvious - even though there are no "real correlations." This research does NOT use statistical inference testing. But rather, a technical analysis relative maxima and minima trading rule, consistently applied over 81 years. Therefore, data snooping can NOT and does NOT occur in this research. In addition, the data sets in this study are split in two. Beginning with a random start date for results comparison, and each segment is reported on separately which reproduces an out-of-sample study. Confirming this research's reported results.

This research specifically accounts for, and overcomes, all of Fama (1998) and Malkiel's (2003) empirical design testing objections. Thus, testing tenet number three in this empirical research is complete.

Fama's $(1965,1995)$ 45-year old challenge for technical analysis is to "rigorously test a trading rule to show it can consistently make better than chance predictions of stock prices." For conclusive results, the technical analysis trading rule should beat a benchmark naïve buy and hold policy, at less risk, which would then call the EMT into question. Fama $(1965,1995)$ says testing a technical analysis trading rule, when compared with a benchmark naïve buy-and-hold policy, is empirical. So, no new financial theories are needed.

\subsection{Three Steps Remove Random Unsystemic Risk from the Data and Smoothes Price Volatility}

Steady, systemic market risk and random unsystemic risk make up individual company stock price movements. As much as $50 \%$ of a company's stock price actions are random unsystemic risk variations associated with the internal circumstances within that particular company. The remaining 50\% of a company's stock price movements represent only steady, systemic market risk. The random unsystemic risk factor is the chaotic portion of the stock price data - that if removed, leaves only the steady, systemic market risk of the overall market which may then be analyzed to test the EMT's third tenet.

Rather than studying individual company stock price behavior which includes the randomness of unsystemic risk - as evaluated in the many referenced research articles in the literature, including Alexander's filter rule tests (Fama, 1995). Instead, only steady, systemic market risk is analyzed by using proxies for the stock market. This research employs two S\&P 500 Index portfolios. Portfolio B for active trading and portfolio A as the benchmark portfolio. Focusing only on steady, systemic market risk which removes much of the random or chance stock market price behavior from the research data.

When investing over 1, 2, 3, 4, 5 years or more-day-to-day stock price movements are immaterial to trading success and may be thought of as just daily market chatter. Concentrating on daily price movements of individual company stock or the stock market is not the correct question. Day-to-day stock price action is volatile. To dampen out this daily chatter and give perspective to what is occurring long-term in the stock market, S\&P 500 Index "monthly price data" are used to smooth out stock price volatility.

Monthly price data are important in dampening out day-to-day price movements. However, using last month's price to predict next month's price is also not conducive to long-term trend development. To further smooth price variations and focus on steady, systemic market risk in the stock market. Nine and two-month simple moving average (SMA) trend lines are fit to the S\&P 500 Index monthly price data for actively managed portfolio B, smoothing out data volatility. Thus, giving an overall view of the long-term stock market trend which is the third step in removing much of the random stock market price behavior from the research data. Focusing only on steady, systemic market risk in the data and smoothing stock price volatility - to lessen random variations - is a major difference between this paper and the referenced RET and EMT research.

\section{Empirical Results}

Portfolios A and B-when invested in the stock market-are in identical S\&P 500 Index no-load mutual funds. Portfolios A and B, each originally invest $\$ 1,000$ dollars. Portfolio B may trade into the S\&P 500 Index no-load mutual fund or out, earning interest on risk-free 3-month T-bills. All S\&P 500 Index no-load mutual fund shares or 
3-month T-bills are redeemed for cash at the study's conclusion, on December 31, 2008. All stock market trades are performed at the close of trading on the first trading day of month $t+1$.

Portfolio A is the buy and hold strategy. One thousand dollars are invested - at the close of trading on the first trading day of 1928 , on January $3^{\text {rd }}$-in a S\&P 500 Index no-load mutual fund at the S\&P 500 Index price of $\$ 17.76$ dollars for each share. The 56.306 shares bought are held until redeemed on Dec. 31, 2008 for the S\&P 500 Index price of $\$ 903.25$ dollars for each share, equaling $\$ 50,858.39$ dollars.

When portfolios A and B are concurrently invested in S\&P 500 Index mutual funds, identical dividends are paid to both portfolios which are excluded from these results. From 1928 through 1959, portfolio B is periodically invested at the risk-free 3-month T-bill interest rate. Shares are added to portfolio A because S\&P 500 Index dividend yields are higher than 3-month T-bill interest rates. Portfolio A adds dividend-interest differential payments at the rate of $4.26 \%$ each year or 0.00355 each month. Table 1. S\&P 500 Index portfolio A: added shares - 1928 through 1959, steps through the added share calculations.

The added portfolio A shares, because of dividend-interest differential payments, increase from 56.306 to 91.817 shares, up through the end of 1959. Each time portfolio B is traded out of the S\&P 500 Index no-load mutual fund into 3-month T-bills, portfolio A receives higher dividends than portfolio B receives in interest. Dividend-interest differential accrues on Mar. 1, 1933 by taking portfolio A's 56.306 shares, times S\&P 500 Index share price of $\$ 5.77$, equaling $\$ 324.89$ dollars, times 27 months. Which represents the total time period before portfolio B is transferred back into the S\&P 500 Index no-load mutual fund-times 0.00355 , to equal $\$ 31.14$ dollars. Representing the dividend-interest differential earned and credited to portfolio A. The 5.397 shares added to portfolio A-shown in the last column of Table 1 -is calculated by dividing the $\$ 31.14$ dollars of dividend-interest differential earned, by the S\&P 500 Index share price of $\$ 5.77$. From 1928 through 1959, each time portfolio B earns interest by trading out of the stock market, portfolio A is credited with the difference because dividend yields are higher than interest payments.

Calculating portfolio A's total final value is as follows. The added S\&P 500 shares, because of dividend-interest differential payment calculations, are 35.511 shares (i.e., 91.817 ending shares, minus the 56.306 shares originally bought), times the S\&P 500 Index redemption price on December 31, 2008 of $\$ 903.25$ - shown on Table 2 - equaling \$32,075.31 dollars. The total value of buy-and-hold S\&P 500 Index portfolio A on December 31, 2008 is $\$ 82,933.70$ dollars (i.e., $\$ 50,858.39+\$ 32,075.31$ ).

The results for portfolio B are determined by trading in-and-out of the S\&P 500 Index no-load mutual fund. Based on S\&P 500 Index nine and two-month SMA trend lines and relative maxima and minima trading rule, shown in Table 2. S\&P 500 Index portfolio B: gain from trading - 1928 through 2008.

The beginning \$1,000 dollar investment in S\&P 500 Index portfolio B on Jan. 3, 1928 of 56.306 shares, at \$17.76 dollars for each share, is redeemed on Dec. 2, 1929 at $\$ 20.95$ for each share. Totaling $\$ 1,179.61$ dollars. From Dec. 2, 1929 to Mar. 1, 1933, portfolio B is out of the stock market and invested in risk-free 3-month T-bills. Portfolio B is reinvested in the S\&P 500 Index on Mar. 1, 1933, at \$5.77 dollars for each share-buying 204.438 shares. Portfolio B is redeemed on May 1, 1934 for $\$ 2,138.42$ dollars (i.e., 204.438 shares, times $\$ 10.46$ for each share).

The original $\$ 1,000$ investment in the S\&P 500 Index portfolio B grows to $\$ 151,484.00$ dollars (i.e., 108.558 shares, times $\$ 1,395.42$ for each share). When redeemed on Feb. 1, 2008 for 3-month T-bills which earn interest until the close of this study, on Dec. 31, 2008. The interest-dividend differential payment calculations for portfolio B are included in Table 3. S\&P 500 Index portfolio B: added shares - 1960 through 2008.

Beginning in 1960, 3-month T-bill interest rates on average are higher than S\&P 500 Index dividend yields. The interest rate versus dividend yield differential advantage shifts to portfolio B which adds interest-dividend differential payments at the rate of $2.34 \%$ each year or 0.00195 each month. When S\&P 500 Index portfolio B is invested in 3-month T-bills.

Portfolio B total shares from trading, shown in Table 2 (which are transferred and listed for the correct date in the second column on Table 3)-begin the added shares earned from interest-dividend differential calculations. Portfolio B redeems all S\&P 500 Index shares on Mar. 1, 1960 and buys 3-month T-bills, holding them for 11 months, and then reenters the stock market on Feb. 1, 1961. The added share calculation for the interest-dividend differential payment on Feb. 1, 1961 is: 137.826 shares, times the each share S\&P 500 Index price of $\$ 61.90$, equaling $\$ 8,531.43$ dollars-times 11 months invested in T-bills, times 0.00195 each month, to equal $\$ 183.00$ dollars earned - which is listed in the second to last column on Table 3. The interest-dividend differential payment of $\$ 183.00$ dollars is divided by the S\&P 500 Index price of $\$ 61.90$, resulting in 2.956 added shares which is shown in the last column of Table 3 . The added portfolio B shares, because of interest-dividend differential payments from 1960 through 2008, totals 39.032 shares - shown in the lower right-hand corner of Table 3.

Portfolio B is traded out of the S\&P 500 Index no-load mutual fund into 3-month T-bills on Feb. 1, 2008. With added shares earned because of the interest-dividend differential, equaling 35.435 shares (i.e., 39.032 shares, minus 3.597 shares earned after Feb. 1, 2008), times \$1,395.42 (i.e., the S\&P 500 Index share price on Feb. 1, 2008, shown on Table 2). Equaling $\$ 49,446.71$ dollars. Adding in portfolio B's interest-dividend differential earned over 11 months, from Feb. 1, 2008 to Dec. 31, 2008, totals $\$ 3,249.33$ dollars. As shown in row C-12/31/08 on Table 3. The 
total value of interest-dividend differential payments for portfolio B is $\$ 52,696.04$ dollars (i.e.,\$49,446.71 + $\$ 3,249.33)$.

Money in the relative maxima and minima trading rule S\&P 500 Index portfolio B account, on Dec. 31, 2008, equals $\$ 204,180.04$ dollars (i.e., \$151,484.00 + \$52,696.04). Relative maxima and minima trading rule S\&P 500 Index portfolio B-by $\$ 121,246.34$ dollars (i.e., $\$ 204,180.04$ - $\$ 82,933.70$ ) — is $+146 \%$ superior to buy-and-hold S\&P 500 Index portfolio A, from Jan. 3, 1928 to Dec. 31, 2008.

\subsection{Risk-Adjusted Returns}

Portfolio B is superior to portfolio A by $+146 \%$. In addition, each portfolio has a different risk profile. When either portfolio A or B is invested in a S\&P 500 Index no-load mutual fund - a proxy for the stock market - each has a beta value equal to one $\left(B_{A}=1\right)\left(B_{B}=1\right)$. When portfolio B is invested in risk-free 3-month T-bills, its beta value is equal to zero $\left(B_{B}=0\right)$. Portfolio B is in 3-month T-bills for 327-months out of a total planning horizon of 972-months, or $34 \%$ of the time. And is invested in a S\&P 500 Index no-load mutual fund the remaining $66 \%$ of the time.

Using a proportionate portfolio risk weighting measure for 3-month T-bills and the S\&P 500 Index no-load mutual fund, results in a beta value for portfolio $\mathrm{B}\left(B_{B}\right)$ that is linearly additive over the entire 972-months. Equaling: $B_{B}=$ $0.34(0)+0.66(1)=0.66$. The buy-and-hold S\&P 500 Index portfolio A has a beta value equal to one $\left(B_{A}=1\right)$, throughout this study's planning horizon.

Relative maxima and minima trading rule S\&P 500 Index portfolio B-makes $+146 \%$ more money than buy-and-hold S\&P 500 Index portfolio A—and is only 66\% as risky—from Jan. 3, 1928 to Dec. 31, 2008.

\subsection{Out-of-Sample Study Confirms Results}

S\&P Index Services and Federal Reserve Statistical Release, 1928 through 2008, data sets are evenly split in two, and each segment is reported on separately which reproduces an out-of-sample study. The planning horizon for this research is 972-months, from Jan. 3, 1928 to Dec. 31, 2008. The midpoint occurs after 486 months, on May 1, 1967, that coincidently, is an existing reinvestment date, shown on Table 2. For portfolios A and B, on May 1, 1967, the data are divided in half: Segment 1: (Jan. 3, 1928 to May 1, 1967) and Segment 2: (May 1, 1967 to Dec. 31, 2008).

Segment 1: Portfolio A: (Jan. 3, 1928 to May 1, 1967). The value of buy-and-hold S\&P 500 Index portfolio A at the close of trading on May 1, 1967 is 91.817 shares, from Table 1, times the S\&P 500 Index share price of $\$ 93.87$ on May 1, 1967, from Table 2, equaling $\$ 8,618.86$ dollars.

Segment 1: Portfolio B: (Jan. 3, 1928 to May 1, 1967). The value of relative maxima and minima trading rule S\&P 500 Index portfolio B at the close of trading on May 1, 1967 is 111.652 shares, from Table 2. Times the S\&P 500 Index share price of $\$ 93.87$, on May 1,1967 , equaling $\$ 10,480.77$ dollars. Added shares bought with interest-dividend differentials earned, from Table 3, amounts to 7.520 shares, times the S\&P 500 Index share price of $\$ 93.87$, equaling $\$ 705.90$ dollars. The grand total is $\$ 11,186.67$ dollars (i.e., $\$ 10,480.77+\$ 705.90$ ).

Conclusion for Segment 1: (Jan. 3, 1928 to May 1, 1967). The gain of the relative maxima and minima trading rule S\&P 500 Index portfolio B, over buy-and-hold S\&P 500 Index portfolio A, is $\$ 2,567.81$ dollars (i.e., $\$ 11,186.67$ $\$ 8,618.86)$ or $+30 \%$, at only $64 \%$ of the risk $\left(B_{B}=0.64\right)$. Portfolio B is in risk-free 3-month T-bills for 173-months, out of 486-months.

Segment 2: Portfolio A: (May 1, 1967 to Dec. 31, 2008). On May 1, 1967, buy-and-hold S\&P 500 Index portfolio A's value is $\$ 8,618.86$ dollars, while relative maxima and minima trading rule S\&P 500 Index portfolio B's value is $\$ 11,186.67$ dollars. Portfolio A's value on Dec. 31, 2008 is $\$ 82,933.70$, less portfolio A's value on May 1, 1967 of $\$ 8,618.86$, equaling $\$ 74,314.84$ dollars of profit earned, from May 1, 1967 to Dec. 31, 2008.

Segment 2: Portfolio B: (May 1, 1967 to Dec. 31, 2008). Portfolio B's value on Dec. 31, 2008 is $\$ 204,180.04$, less portfolio B's value on May 1, 1967 of \$11,186.67, equaling \$192,993.37 dollars of profit earned, from May 1, 1967 to Dec. 31, 2008 .

Conclusion for Segment 2: (May 1, 1967 to Dec. 31, 2008). The gain of the relative maxima and minima trading rule S\&P 500 Index portfolio B, over buy-and-hold S\&P 500 Index portfolio A, is $\$ 118,678.53$ dollars (i.e., $\$ 192,993.37-\$ 74,314.84)$ or $+160 \%$, at just $68 \%$ of the risk $\left(B_{B}=0.68\right)$. Portfolio B is in 3-month T-bills for 154-months, out of 486-months.

Splitting the data sets at their midpoints show that actively managed portfolio B is $+30 \%$ superior to buy-and-hold portfolio A, from Jan. 3, 1928 to May 1, 1967—at only $64 \%$ of the risk. Increasing to $+160 \%$ superior from May 1 , 1967 to Dec. 31, 2008 - at just $68 \%$ of the risk. The out-of-sample study confirms this research's conclusion, calling the RET and EMT into question.

\section{Conclusion}

This research empirically tests the Rational Expectations Theory (RET) and the Efficient Market Theory (EMT) using a new technical analysis relative maxima and minima trading rule. The new trading rule decides when portfolio B should be either in a S\&P 500 Index no-load mutual fund-or out, and invested in interest bearing, risk-free 3-month Treasury bills (T-bills) - from 1928 through 2008 - and compares results to a benchmark naïve buy-and-hold policy. 
Relative maxima and minima trading rule S\&P 500 Index portfolio B is $+146 \%$ superior to the buy-and-hold benchmark S\&P 500 Index portfolio A (i.e., $\$ 82,933.70$ versus $\$ 204,180.04$ dollars), over a duration of 81 years. And is only $66 \%$ as risky as the buy-and-hold benchmark S\&P 500 Index portfolio A-because of investing in risk-free 3-month T-bills for 327 out of 972-months. The out-of-sample study confirms this research's conclusion which calls the RET and EMT into question.

The explanation offered about why the new relative maxima and minima trading rule succeeds is because of market participants' emotions. Investor fear and panic selling plunges stock prices downward below equity intrinsic values at market bottoms. Investor greed brings stock prices above equity intrinsic values at market tops. Where investors act with a herd mind-set and trade based on the madness of crowd behavior rather than on market fundamentals — spurred on by the financial media—resulting in market bubbles.

The relative maxima and minima trading rule is not a short-term or intermediate term trading strategy; nor does it apply to specific company stock. Interest in this new rule is not limited solely to trading the S\&P 500 Index. Once an investor identifies the long-term stock market trend-long or short positions in individual common stock may be determined using other methods. Future research in economics and finance should focus on improving the Rational Expectations Theory and Efficient Market Theory.

\section{References}

Ashley, R. (1986). A nonparametric, distribution-free test for serial independence in stock returns. Journal of Financial and Quantitative Analysis, 21, 221-227.

Ball, R., \& Brown, P. (1968). An empirical evaluation of accounting income numbers. Journal of Accounting Research, 6, 159-178.

Basak, G. K., Jagannathan, R., \& Ma, T. (2009). Jackknife estimator for tracking error variance of optimal portfolios. Management Science, 55, 990-1002.

Bernard, V. L. \& Thomas, J. K. (1990). Evidence that stock prices do not fully reflect the implications of current earnings for future earnings. Journal of Accounting and Economics, 13, 305-340.

Blasco, N., \& Ferreruela, S. (2008). Testing intentional herding in familiar stocks: An experiment in an international context. Journal of Behavioral Finance, 9, 72-84.

Curcio, R., Goodhart, C., Guillaume, D. \& Payne, R. (1997). Do technical trading rules generate profits? Conclusions from the intra-day foreign exchange market. International Journal of Finance \& Economics, 2, 267-280.

Edwards, R. D., Magee, J. \& Bassetti, W. H. C. (Editor). (2001). Technical Analysis of Stock Trends. (8 ${ }^{\text {th }}$ ed.). New York: St. Lucie Press.

Fama, E. F. (1965). Random walks in stock market prices. Financial Analysts Journal, 21, 55-59.

Fama, E. F. (1970). Efficient capital markets: A review of theory and empirical work. Journal of Finance, 25, 383-417.

Fama, E. F. (1991). Efficient capital markets: II. Journal of Finance, 46, 1575-1617.

Fama, E. F. (1995). Random walks in stock market prices. Financial Analysts Journal, 51, 75-80.

Fama, E. F. (1998). Market efficiency, long-term returns, and behavioral finance. Journal of Financial Economics, 49, 283-306.

Gift, M. J., Gift, P. \& Yang, Y. (2010). Financial market reactions to earnings announcements and earnings forecast revisions: Evidence from the U.S. and China. International Journal of Business and Finance Research, 4, 85-96.

Graham, J. R., Harvey, C. R. \& Huang, H. (2009). Investor competence, trading frequency, and home bias. Management Science, 55, 1094-1106.

Grossman, S. J. \& Stiglitz, J. E. (1980). On the impossibility of informationally efficient markets. American Economic Review, 70, 393-408.

Hsieh, M., Yang, T. \& Yang, Y. (2010). Positive trading effects and herding behavior in Asian markets: Evidence from mutual funds. International Journal of Business and Finance Research, 4, 177-188.

Lento, C. (2009). Long-term dependencies and the profitability of technical analysis. International Research Journal of Finance and Economics, 29, 126-133.

Lo, A. W. (2002). Bubble, rubble, finance in trouble? Journal of Behavioral Finance, 3, 76-86.

Lo, A. W. \& MacKinlay, A. C. (1988). Stock market prices do not follow random walks: Evidence from a simple specifications test. Review of Financial Studies, 1, 41-66.

Lucas, R. E., Jr. (1972). Expectations and the neutrality of money. Journal of Economic Theory, 4, 103-124.

Malkiel, B. G. (2003). The efficient market hypothesis and its critics. Journal of Economic Perspectives, 17, 59-82.

Malkiel, B. G. (2005). Reflections on the Efficient Market Hypothesis: 30 years later. The Financial Review, 40, $1-9$. 
Muth, J. F. (1961). Rational expectations and the theory of price movements. Econometrica, 29, 315-335.

Peress, J. (2010). Product market competition, insider trading, and stock market efficiency. Journal of Finance, 65, $1-43$.

Rosenberg, B. \& Rudd, A. (1982). Factor-related and specific returns of common stocks: Serial correlation and market inefficiency. Journal of Finance, 37, 543-554.

Samuelson, P. A. (1965). Proof that properly anticipated prices fluctuate randomly. Industrial Management Review, 6, 41-49.

Shiller, R. J. (2000). Measuring bubble expectations and investor confidence. Journal of Behavioral Finance, 1, 49-60.

Sullivan, R., Timmermann, A. \& White, H. (1999). Data-snooping, technical trading rule performance, and the bootstrap. Journal of Finance, 54, 1647-1691.

Summers, L. H. (1986). Does the stock market rationally reflect fundamental values? Journal of Finance, 41, 591-601.

Table 1. S\&P 500 Index portfolio A: added shares - 1928 through 1959

\begin{tabular}{|c|c|c|c|c|c|c|}
\hline Date & $\begin{array}{l}\text { Total Shares } \\
\text { (Rounded) }\end{array}$ & $\begin{array}{lr}\text { S\&P } & 500 \\
\text { Index } & \text { Price } \\
\end{array}$ & $\begin{array}{l}\text { Portfolio A } \\
\text { Value }\end{array}$ & Months & $\begin{array}{l}\text { Dividend-Interest } \\
\text { Diff. }\end{array}$ & $\begin{array}{l}\text { Added } \\
\text { Shares }\end{array}$ \\
\hline \multicolumn{7}{|l|}{ (R) $12 / 2 / 29$} \\
\hline (I) $\quad 3 / 1 / 33$ & 56.306 & $\$ 5.77$ & $\$ 324.89$ & $27 \mathrm{mo}$ & 31.14 & 5.397 \\
\hline \multicolumn{7}{|l|}{ (R) $5 / 1 / 34$} \\
\hline (I) $8 / 1 / 35$ & 61.703 & 11.04 & 681.20 & 15 & 36.27 & 3.285 \\
\hline \multicolumn{7}{|l|}{ (R) $8 / 2 / 37$} \\
\hline (I) $10 / 1 / 38$ & 64.988 & 12.46 & 809.75 & 14 & 40.24 & 3.230 \\
\hline \multicolumn{7}{|l|}{ (R) $5 / 1 / 39$} \\
\hline (I) $12 / 1 / 39$ & 68.218 & 12.29 & 838.40 & 8 & 23.81 & 1.937 \\
\hline \multicolumn{7}{|l|}{ (R) $7 / 1 / 40$} \\
\hline (I) $12 / 1 / 42$ & 70.155 & 9.28 & 651.04 & 30 & 69.34 & 7.472 \\
\hline \multicolumn{7}{|l|}{ (R)10/1/46 } \\
\hline (I) $8 / 1 / 47$ & 77.627 & 15.80 & 1226.51 & 10 & 43.54 & 2.756 \\
\hline \multicolumn{7}{|l|}{ (R) $1 / 2 / 48$} \\
\hline (I) $7 / 1 / 48$ & 80.383 & 16.70 & 1342.40 & 6 & 28.59 & 1.712 \\
\hline \multicolumn{7}{|l|}{ (R) $4 / 1 / 49$} \\
\hline (I) $10 / 1 / 49$ & 82.095 & 15.52 & 1274.11 & 6 & 27.14 & 1.749 \\
\hline \multicolumn{7}{|l|}{ (R) $6 / 1 / 53$} \\
\hline (I) $3 / 1 / 54$ & 83.844 & 26.25 & 2200.91 & 11 & 85.95 & 3.274 \\
\hline \multicolumn{7}{|l|}{ (R) $2 / 1 / 57$} \\
\hline (I) $\quad 8 / 1 / 57$ & 87.118 & 47.79 & 4163.37 & 6 & 88.68 & 1.856 \\
\hline \multicolumn{7}{|l|}{ (R)11/1/57 } \\
\hline (I) $\quad 8 / 1 / 58$ & 88.974 & 47.49 & 4225.38 & 9 & 135.00 & 2.843 \\
\hline Totals & $91.817 \mathrm{sh}$ & & & $142 \mathrm{mo}$ & $\$ 632.32$ & $35.511 \mathrm{sh}$ \\
\hline
\end{tabular}


Table 2. S\&P 500 Index portfolio B: gain from trading - 1928 through 2008

\begin{tabular}{|c|c|c|c|}
\hline Date & $\begin{array}{l}\text { Total Shares } \\
\text { (Rounded) }\end{array}$ & $\begin{array}{l}\text { S\&P } 500 \text { Index } \\
\text { Price }\end{array}$ & Portfolio B Value \\
\hline (I) $1 / 3 / 28$ & 56.306 & $\$ 17.76$ & $\$ 1000.00$ \\
\hline (R) $12 / 2 / 29$ & & 20.95 & 1179.61 \\
\hline $3 / 1 / 33$ & 204.438 & 5.77 & \\
\hline (R) $5 / 1 / 34$ & & 10.46 & 2138.42 \\
\hline $8 / 1 / 35$ & 193.697 & 11.04 & \\
\hline (R) $8 / 2 / 37$ & & 17.07 & 3306.41 \\
\hline (I) $10 / 1 / 38$ & 265.362 & 12.46 & \\
\hline (R) $5 / 1 / 39$ & & 10.86 & 2881.83 \\
\hline (I) $12 / 1 / 39$ & 234.486 & 12.29 & \\
\hline (R) $\quad 7 / 1 / 40$ & & 9.87 & 2314.38 \\
\hline (I) $12 / 1 / 42$ & 249.394 & 9.28 & \\
\hline$(\mathrm{R}) 10 / 1 / 46$ & & 14.92 & 3720.96 \\
\hline (I) $8 / 1 / 47$ & 235.504 & 15.80 & \\
\hline (R) $1 / 2 / 48$ & & 15.34 & 3612.63 \\
\hline (I) $7 / 1 / 48$ & 216.325 & 16.70 & \\
\hline (R) $\quad 4 / 1 / 49$ & & 14.94 & 3231.90 \\
\hline (I) $10 / 1 / 49$ & 208.241 & 15.52 & \\
\hline (R) $6 / 1 / 53$ & & 24.15 & 5029.02 \\
\hline (I) $3 / 1 / 54$ & 191.582 & 26.25 & \\
\hline (R) $\quad 2 / 1 / 57$ & & 44.62 & 8548.39 \\
\hline (I) $8 / 1 / 57$ & 178.874 & 47.79 & \\
\hline (R) $11 / 1 / 57$ & & 40.44 & 7233.66 \\
\hline (I) $8 / 1 / 58$ & 152.320 & 47.49 & \\
\hline (R) $3 / 1 / 60$ & & 56.01 & 8531.44 \\
\hline (I) $2 / 1 / 61$ & 137.826 & 61.90 & \\
\hline (R) $\quad 6 / 1 / 62$ & & 59.38 & 8184.11 \\
\hline (I) $4 / 1 / 63$ & 122.425 & 66.85 & \\
\hline (R) $7 / 1 / 66$ & & 85.61 & 10480.80 \\
\hline (I) $5 / 1 / 67$ & 111.652 & 93.87 & \\
\hline (R) $8 / 1 / 69$ & & 93.47 & 10436.11 \\
\hline (I) $3 / 1 / 71$ & 107.589 & 97.00 & \\
\hline (R) $1 / 3 / 72$ & & 101.67 & 10938.57 \\
\hline (I) $4 / 3 / 72$ & 101.773 & 107.48 & \\
\hline (R) $7 / 2 / 73$ & & 102.90 & 10472.44 \\
\hline (I) $6 / 2 / 75$ & 113.118 & 92.58 & \\
\hline (R) $5 / 2 / 77$ & & 98.93 & 11190.76 \\
\hline (I) $\quad 9 / 1 / 78$ & 107.936 & 103.68 & \\
\hline (R) $10 / 1 / 81$ & & 117.08 & 12637.15 \\
\hline (I) $12 / 1 / 82$ & 91.098 & 138.72 & \\
\hline (R) $3 / 1 / 84$ & & 158.19 & 14410.79 \\
\hline (I) $12 / 3 / 84$ & 88.507 & 162.82 & \\
\hline (R) $12 / 1 / 87$ & & 232.00 & 20533.62 \\
\hline (I) $\quad 9 / 1 / 88$ & 79.480 & 258.35 & \\
\hline (R) $6 / 1 / 90$ & & 363.16 & 28863.96 \\
\hline (I) $\quad 3 / 1 / 91$ & 77.912 & 370.47 & \\
\hline (R) $5 / 2 / 94$ & & 453.02 & 35295.69 \\
\hline (I) $\quad 2 / 1 / 95$ & 75.033 & 470.40 & \\
\hline (R) $11 / 1 / 00$ & & 1421.22 & 106638.40 \\
\hline (I) $\quad 7 / 1 / 03$ & 108.558 & 982.32 & \\
\hline (R) $\quad 2 / 1 / 08$ & & 1395.42 & $\$ 151484.00$ \\
\hline (C) $12 / 31 / 08$ & 167.710 & 903.25 & \\
\hline
\end{tabular}


Table 3. S\&P 500 Index portfolio B: added shares - 1960 through 2008

\begin{tabular}{|c|c|c|c|c|c|c|}
\hline Date & $\begin{array}{l}\text { Total } \\
\text { Shares - } \\
\text { Table } 2\end{array}$ & $\begin{array}{lr}\text { S\&P } & 500 \\
\text { Index Price }\end{array}$ & $\begin{array}{l}\text { Portfolio B } \\
\text { Value }\end{array}$ & Months & $\begin{array}{l}\text { Interest- } \\
\text { Dividend Diff. }\end{array}$ & $\begin{array}{l}\text { Added } \\
\text { Shares }\end{array}$ \\
\hline \multicolumn{7}{|l|}{ (R) $3 / 1 / 60$} \\
\hline (I) $2 / 1 / 61$ & 137.826 & $\$ 61.90$ & $\$ 8531.43$ & $11 \mathrm{mo}$ & $\$ 183.00$ & 2.956 \\
\hline \multicolumn{7}{|l|}{ (R) $6 / 1 / 62$} \\
\hline (I) $4 / 1 / 63$ & 122.425 & 66.85 & 8184.11 & 10 & 159.59 & 2.387 \\
\hline \multicolumn{7}{|l|}{ (R) $7 / 1 / 66$} \\
\hline (I) $5 / 1 / 67$ & 111.652 & 93.87 & 10480.77 & 10 & 204.38 & 2.177 \\
\hline \multicolumn{7}{|l|}{ (R) $8 / 1 / 69$} \\
\hline (I) $3 / 1 / 71$ & 107.589 & 97.00 & 10436.13 & 19 & 386.66 & 3.986 \\
\hline \multicolumn{7}{|l|}{ (R) $1 / 3 / 72$} \\
\hline (I) $4 / 3 / 72$ & 101.773 & 107.48 & 10938.56 & 3 & 63.99 & 0.595 \\
\hline \multicolumn{7}{|l|}{ (R) $7 / 2 / 73$} \\
\hline (I) $6 / 2 / 75$ & 113.118 & 92.58 & 10472.46 & 23 & 469.69 & 5.073 \\
\hline \multicolumn{7}{|l|}{ (R) $5 / 2 / 77$} \\
\hline (I) $9 / 1 / 78$ & 107.936 & 103.68 & 11190.80 & 16 & 349.15 & 3.368 \\
\hline \multicolumn{7}{|l|}{ (R)10/1/81 } \\
\hline (I) $12 / 1 / 82$ & 91.098 & 138.72 & 12637.11 & 14 & 344.99 & 2.487 \\
\hline \multicolumn{7}{|l|}{ (R) $3 / 1 / 84$} \\
\hline (I) $12 / 3 / 84$ & 88.507 & 162.82 & 14410.71 & 9 & 252.91 & 1.553 \\
\hline \multicolumn{7}{|l|}{ (R) $12 / 1 / 87$} \\
\hline (I) $\quad 9 / 1 / 88$ & 79.480 & 258.35 & 20533.66 & 9 & 360.37 & 1.395 \\
\hline \multicolumn{7}{|l|}{ (R) $\quad 6 / 1 / 90$} \\
\hline (I) $3 / 1 / 91$ & 77.912 & 370.47 & 28864.06 & 9 & 506.56 & 1.367 \\
\hline \multicolumn{7}{|l|}{ (R) $\quad 5 / 2 / 94$} \\
\hline (I) $2 / 1 / 95$ & 75.033 & 470.40 & 35295.52 & 9 & 619.44 & 1.317 \\
\hline \multicolumn{7}{|l|}{ (R)11/1/00 } \\
\hline (I) $\quad 7 / 1 / 03$ & 108.558 & 982.32 & 106638.69 & 32 & 6654.25 & 6.774 \\
\hline \multicolumn{7}{|l|}{ (R) $\quad 2 / 1 / 08$} \\
\hline $\mathrm{C}-12 / 31 / 08$ & 167.710 & 903.25 & 151484.05 & 11 & 3249.33 & 3.597 \\
\hline Totals & & & & $185 \mathrm{mo}$ & $\$ 13804.31$ & $39.032 \mathrm{sh}$ \\
\hline
\end{tabular}




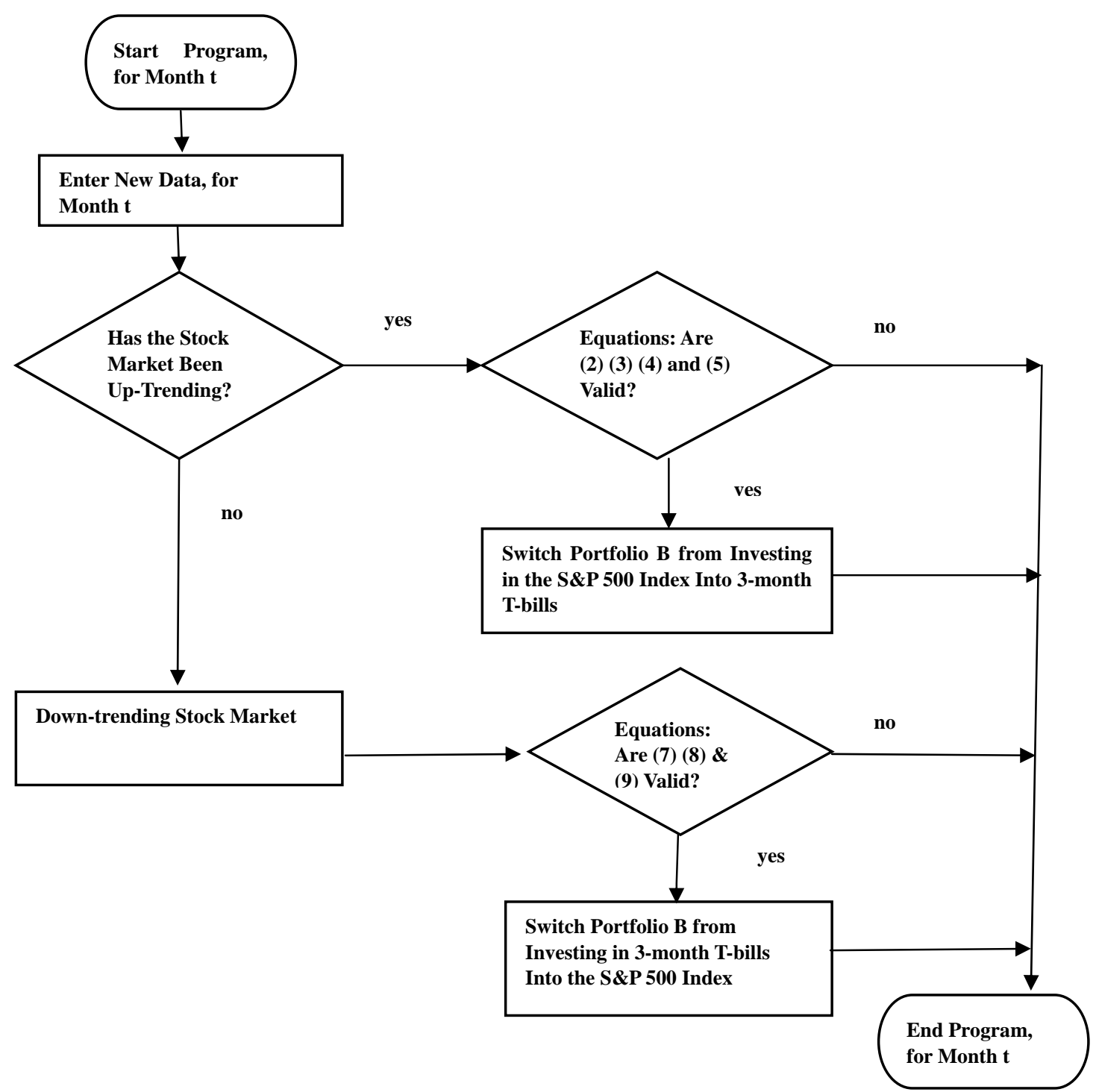

Figure 1. Portfolio B: relative maxima and minima trading rule flowchart 